
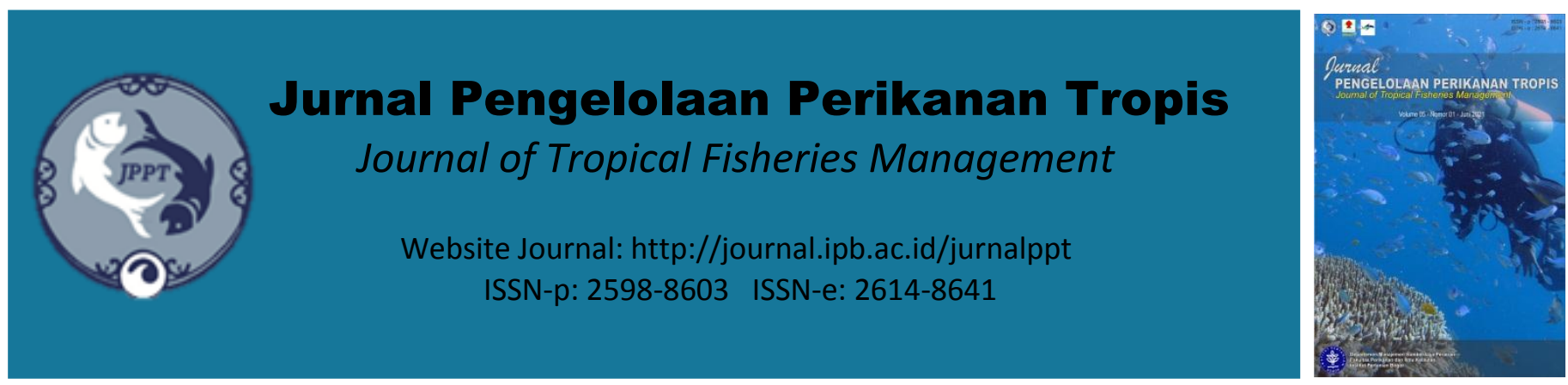

\title{
Pendugaan Status Sumberdaya Perikanan Skala Kecil di Kota Semarang
}

\author{
(Estimation of the Status of Small-Scale Fisheries Resources in Semarang City)
}

\author{
Hendi Kristiana $^{1}$, Jamaludin Malik ${ }^{1, *}$, Nur Anwar ${ }^{1}$
}

${ }^{1}$ Dinas Kelautan dan Perikanan Provonsi Jawa Tengah

\section{INFO ARTIKEL}

\section{Histori Artikel}

Recevied: 28 Februari 2021

Accepted: 30 April 2021

\author{
Kata Kunci: \\ CPUE, MSY, overcapacity, \\ overfishing
}

Keywords:

CPUE, MSY, overcapacity, overfishing

\section{Korespondensi Author:}

Jamaludin Malik,

Dinas Kelautan dan Perikanan Provinsi

Jawa Tengah

Email: jamesmely@gmail.com

\section{ABSTRAK}

Perikanan di Kota Semarang didominasi oleh perikanan skala kecil. Hal ini ditandai dengan penggunaan armada perikanan paling besar 10 gros ton yang beroperasi di dekat pantai. Data statistik perikanan selama 10 tahun (2010-2019) terlihat hasil tangkapan yang mulai menurun, sementara perkembangan jumlah unit penangkapan yang semakin meningkat. Hal ini mengindikasikan stok ikan mulai berkurang dan tingkat pemanfaatan sumberdaya perikanan mengarah overfishing. Hal tersebut diperkuat dengan hasil pengamatan langsung di lapangan yang menunjukkan jumlah hasil tangkapan cenderung sedikit dan ukuran ikan yang tertangkap cenderung kecil. Tujuan penelitian ini adalah menganalisis status sumberdaya perikanan skala kecil di Kota Semarang. Metode yang dipakai dalam penelitian ini adalah analisis data runtun waktu (time series) produksi surplus yaitu data dari hasil tangkapan (ton/tahun) dan jumlah alat tangkap (unit), dalam kurun waktu 10 tahun (2010-2019), untuk menghitung nilai catch per-unit effort (CPUE), potensi maksimum lestari $(M S Y)$, jumlah effort optimum $\left(\mathrm{f}_{\mathrm{opt}}\right)$, tingkat pemanfaatan (TP) dan tingkat kapasitas (TK). Penelitian ini diperoleh hasil adanya tren penurunan CPUE; hasil tangkapan/produksi perikanan eksisting tahun 2019 telah melewati nilai $M S Y$-nya yaitu sebesar 479 ton/tahun (Schaefer) dan 439,11 ton/tahun (Fox); tingkat pemanfaatan lebih dari $100 \%$ yaitu sebesar $108-127 \%$ (Schaefer) dan 118-138\% (Fox), sehingga perikanan skala kecil di Kota Semarang berada pada tingkat over-exploited. Berdasarkan analisis $\mathrm{f}_{\text {opt }}$ menunjukkan jumlah alat tangkap yang digunakan $\left(\mathrm{f}_{\text {existing }}\right)$ telah melebihi jumlah optimumnya dengan tingkat kapasitas penangkapan melebihi 100\%, sehingga perikanan skala kecil di Kota Semarang telah mengalami kelebihan kapasitas penangkapan (overcapacity).

\section{ABSTRACT}

Fisheries in Semarang City are dominated by small-scale fisheries. This is indicated by the use of the largest fishing fleet of 10 gross tons operating near the coast. Fisheries statistics for 10 years (2010-2019) show that fishery catches have begun to decline, while the number of fishing units have increased. This indicates that fish stocks are starting to decrease and the level of utilization of fisheries resources leads to overfishing. This is supported by the results of direct observation in the field which showed that the number of catches tends to be small and the size of caught fish tends to be small. This study aims to analyze the status of small-scale fisheries in Semarang City. The method used in this study is the analysis of time series surplus production, namely data from the catch (ton/year) and the number of fishing gear (unit) within 10 years (2010-2019), to calculate the catch per-unit effort (CPUE), maximum sustainable yield (MSY), optimum effort $\left(f_{\text {opt }}\right)$, utilization rate (TP) and capacity level (TK). This study was obtained results of a downward trend in CPUE; the existing fishery catch or production in 2019 has exceeded the MSY value is 479 tons/year (Schaefer) and 439.11 tons/year (Fox); utilization rate of more than 100\% which is 108-127\% (Schaefer) and 118-138\% (Fox), so that small-scale fisheries in Semarang City are at the level of over-exploited. Based on the $f_{\text {opt }}$ analysis, the number of fishing gear used ( $f_{\text {existing }}$ ) has exceeded the optimum effort with a fishing capacity exceeding $100 \%$, so that small-scale fisheries in Semarang City have experienced overcapacity. 


\section{PENDAHULUAN}

Perairan pesisir Kota Semarang merupakan bagian dari Pantai Utara Jawa Tengah, termasuk dalam Wilayah Pengelolaan Perikanan (WPP) 712. Estimasi sumberdaya ikan di WPP 712 menurut Kepmen KP No.47/MEN/2016 tentang estimasi potensi sumberdaya ikan, jumlah tangkapan yang diperbolehkan dan tingkat pemanfaatan sumberdaya ikan adalah 981.680 ribu ton/tahun. Keberadaan sumberdaya perikanan ini sangat penting bagi perekonomian Indonesia, yaitu sebagai sumber protein hewani, banyak menyerap tenaga kerja di usaha perikanan serta berkontribusi pada pendapatan negara.

Perikanan skala kecil merupakan perikanan dengan nelayan yang melakukan kegiatan penangkapan ikan menggunakan kapal penangkap ikan berukuran paling besar 10 gros ton (UU No 7 tahun 2016; Garcia et al. 2008; Batista et al. 2013); dengan jarak penangkapan yang pendek dan dekat pantai (FAO 2017); berbiaya rendah serta hasil tangkapan ikan untuk konsumsi dan dijual lokal (King 2007); memiliki kru armada yang lebih sedikit (Guyader et al. 2012); keberadaannya tergantung pada sumberdaya lokal dan terkena dampak lingkungan sekitar (Mc Clanahan dan Castilla 2007); serta model alternatif kegiatannya lebih mengedepankan kebijakan dan keberlanjutan ekologi (Trimble dan Johnson 2012).

Perikanan skala kecil di Kota Semarang bersifat banyak jenis (multyspecies) dan banyak alat tangkap (multygear). Terdapat 4 jenis ikan dominan yaitu: teri, tembang dan kembung mewakili kelompok pelagis serta petek mewakili kelompok demersal. Sedangkan jenis alat tangkap dominan yang dipakai untuk menangkap terhadap 4 jenis ikan dominan tersebut adalah gill net, arad dan bagan. Berdasarkan data statistik perikanan tangkap Jawa Tengah tahun 2015-2019, di Kota Semarang terlihat tren hasil tangkapan ikan yang sudah mulai menurun sejak tahun 2017 hingga 2019, sedangkan jumlah unit penangkapan terus bertambah dari tahun 2015-2019. Bertambahnya jumlah unit penangkapan ini menimbulkan tingkat eksploitasi terus meningkat. Peningkatan eksploitasi yang berlebih mengindikasikan terjadi kelebihan kapasitas penangkapan (overcapacity). Terjadinya kelebihan kapasitas (overcapacity) ini akan menyebabkan masalah yang lain yaitu terjadinya tangkap lebih (overfishing); penipisan stok; degradasi lingkungan; resiko terjadinya konflik dalam perikanan; banyak nelayan mengalami penurunan laba dan penurunan kualitas hidup (kemiskinan); kurangnya kontribusi perikanan untuk pekerjaan, ketahanan pangan dan pembangunan; kurangnya manajemen dan lemahnya penegakan hukum; kurangnya akses dan informasi; lemahnya mekanisme kelembagaan dan tata kelola. Permasalahan tersebut menjadi kompleks dan sulit ditangani secara parsial, sehingga perlu dikelola agar berkelanjutan. Penelitian ini bertujuan menganalisis status perikanan skala kecil di Kota Semarang untuk pengelolaan berkelanjutan.

Penentuan kondisi status perikanan skala kecil di Kota Semarang ini dilakukan melalui estimasi potensi maksimum lestari (MSY), effort optimum $\left(\mathrm{f}_{\mathrm{opt}}\right)$ serta tingkat pemanfaatan dan tingkat kapasitas penangkapan dengan mengikuti konsep model Schaefer dan Fox. Penentuan ini didasarkan pada analisis data produksi surplus, yaitu dari data hasil tangkapan (catch) dan jumlah upaya penangkapan (effort) dalam kurun waktu 10 tahun. Perikanan dapat dikelola berdasarkan model produksi surplus bila tersedia data hasil tangkapan atau catch dan jumlah upaya penangkapan atau effort (Omori et al. 2016).

\section{METODE}

\section{Jenis, Sumber dan Metode Pengambilan Data}

Jenis data yang digunakan dalam penelitian ini adalah data primer dan sekunder. Data primer diperoleh dari wawancara serta pengisian kuesioner dengan nelayan setempat, pegawai Dinas Perikanan Kota Semarang serta pegawai Dinas Kelautan dan Perikanan Provinsi Jawa Tengah. Data ini meliputi hasil tangkapan ikan (jenis atau komposisi ikan yang tertangkap dan jumlahnya), alat tangkap yang digunakan, tren ukuran ikan dan ukuran mata jaring yang digunakan. Pengambilan data primer ini dimaksudkan untuk mengetahui kondisi di lapangan terkait implikasi kebijakan. Sementara data sekunder diperoleh dari studi dokumentasi/laporan, yaitu dari data runtun waktu (time series) dokumen/laporan statistik perikanan laut selama 10 tahun terakhir yang tersedia (20102019). Data yang digunakan adalah data produksi atau hasil tangkapan (catch) perikanan laut (ton/tahun) serta data jumlah alat tangkap (unit).

\section{Lokasi dan Waktu Penelitian}

Penelitian ini dilaksanakan di perairan pesisir Kota Semarang, Provinsi Jawa Tengah, yang termasuk bagian dari Wilayah Pengelolaan Perikanan (WPP) 712, seperti pada Gambar 1. Pada daerah penangkapan ikan ini terbagi atas 2 jalur penangkapan yaitu jalur 1 (sejauh 4 mil dari bibir pantai), banyak beroperasi alat 


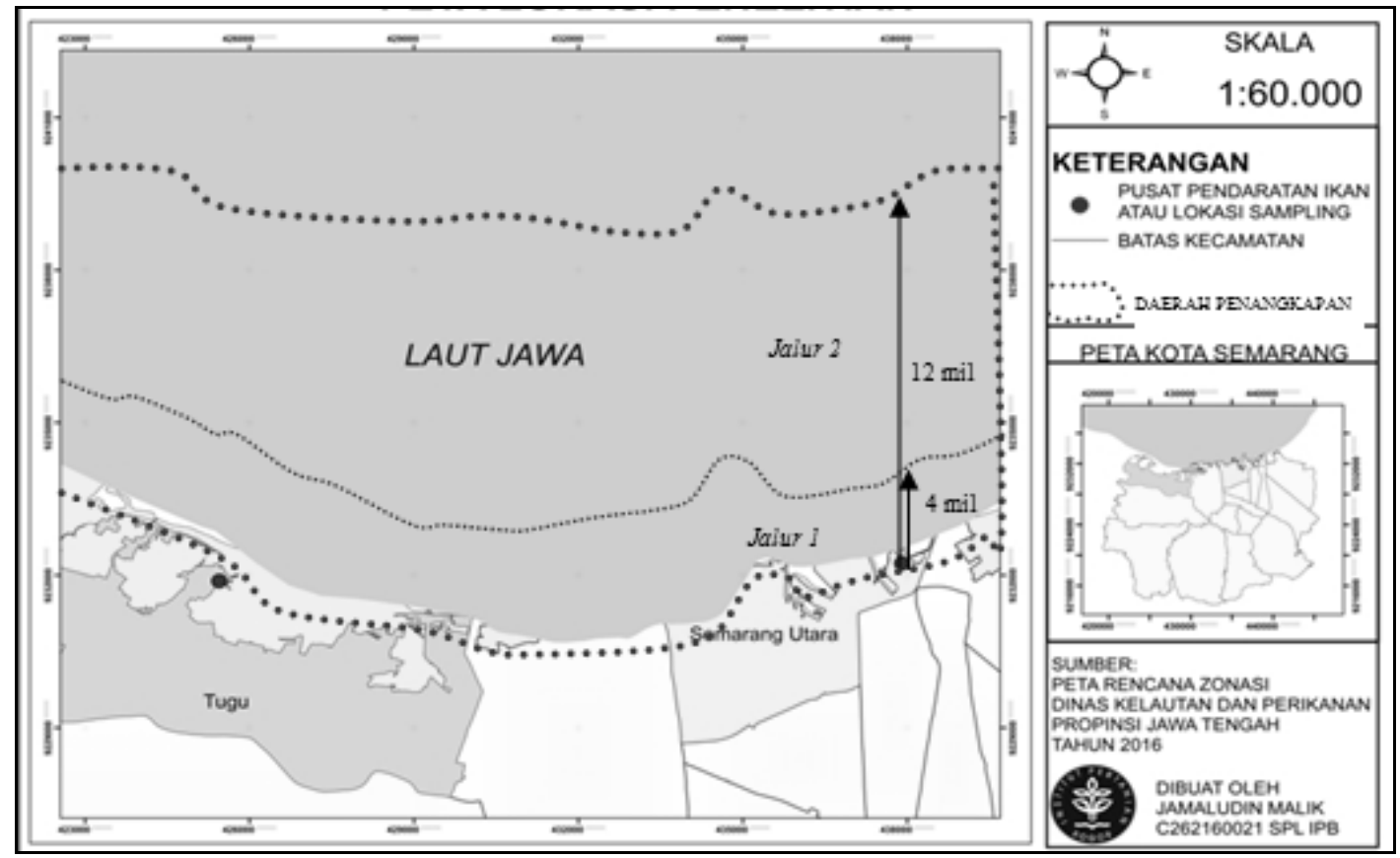

Gambar 1. Peta lokasi penelitian

tangkap Arad dan Gill Net; serta jalur 2 (dari 4 mil sampai 12 mil) didominasi oleh alat tangkap Bagan Perahu. Pengumpulan dan analisis data dilaksanakan selama 5 bulan yaitu AgustusDesember 2020.

\section{Metode Analisis Data}

Data jumlah produksi atau hasil tangkapan (catch) dan data jumlah alat tangkap dianalisis untuk menghitung (i) nilai catch per unit effort (CPUE), (ii) nilai tangkapan maksimum lestari atau maximum sustainable yield (MSY) dan jumlah effort optimum ( $\left.\mathrm{f}_{\mathrm{opt}}\right)$, (iii) tingkat pemanfaatan sumberdaya ikan (TP) dan tingkat kapasitas unit penangkapan (TK).

\section{Catch per Unit Effort (CPUE)}

Nilai CPUE di sini adalah nilai CPUE yang dihitung berdasarkan total jumlah produksi atau hasil tangkapan (total catch) dalam satuan (ton/tahun) dibanding dengan total effort-nya dalam satuan (unit). Dalam Tinungki (2005), Zulbainarni (2016), CPUE dapat diformulasikan sebagai berikut:

CPUE $=\frac{\sum \text { Catch }_{t}}{\sum \text { Effort }_{t}} \quad ; \quad t=\operatorname{tahun}(1,2,3, \ldots, n)$ keterangan :

CPUE $t=$ hasil tangkapan per upaya penangkapan (ton/tahun/unit)

Catch $_{t}=$ jumlah hasil tangkapan (ton/tahun)

Effort $_{t}=$ jumlah upaya penangkapan (unit)

\section{MSY dan $f_{\text {opt }}$}

B. MSY dan $f_{\text {opt }}$ Model Fox (Exponensial)
Pendugaan potensi lestari (MSY) dan jumlah effort optimum $\left(\mathrm{f}_{\mathrm{opt}}\right)$ dapat dilakukan dengan menggunakan model Schaefer dan Fox (Pauly, 1983 dalam Nugraha et al. 2012; Istikasari et al. 2016) sebagai berikut:

\section{A. MSY dan $f_{\text {opt }}$ Model Schaefer (Linier) \\ 1. Hubungan antara CPUE dan effort (f)}

CPUE $=\mathrm{a}+\mathrm{bf}$.

keterangan, dari hubungan linier CPUE dan effort (f), diperoleh:

a : intersep

b : slope

2. Hubungan antara hasil tangkapan (catch) dan effort:

$\mathrm{C} / \mathrm{f}=\mathrm{a}+\mathrm{bf}$

$\mathrm{C}=\mathrm{af}+\mathrm{bf}^{2}$. .2

3. Effort optimum $\left(\mathrm{f}_{\mathrm{opt}}\right)$ diperoleh dari turunan pertama hasil tangkapan (C) terhadap effort sama dengan nol.

$\mathrm{C}=\mathrm{af}+\mathrm{bf}^{2}$

$\mathrm{C}^{\mathrm{l}}=\mathrm{dC} / \mathrm{df}=\mathrm{a}+2 \mathrm{bf}=0$

$2 \mathrm{bf}=-\mathrm{a}$

$\mathrm{f}_{\text {opt }}=-(\mathrm{a} / 2 \mathrm{~b})$

4. Nilai MSY diperoleh dengan mensubstitusikan nilai effort optimum $\left(f_{\mathrm{opt}}\right)$ ke dalam persamaan 3 , sehingga didapatkan:

$$
\begin{aligned}
\mathrm{C}_{\max } & =\mathrm{a}(-\mathrm{a} / 2 \mathrm{~b})+\mathrm{b}\left(\mathrm{a}^{2} / 4 \mathrm{~b}^{2}\right) \\
& =-\mathrm{a}^{2} / 2 \mathrm{~b}+\mathrm{a}^{2} / 4 \mathrm{~b} \\
& =\left(-2 \mathrm{a}^{2}+\mathrm{a}^{2}\right) / 4 \mathrm{~b} \\
\text { MSY } & =\mathrm{C}_{\max }=-\left(\mathrm{a}^{2} / 4 \mathrm{~b}\right) \ldots \ldots . .
\end{aligned}
$$

1. Hubungan $\mathrm{f}$ dengan CPUE 
$\mathrm{CPUE}=\exp (\mathrm{a}+\mathrm{bf})$

keterangan :

a dan b adalah anti log alami (ln) dari intersep

2. Hubungan antara $\mathrm{f}$ dengan $\mathrm{C}$

$\mathrm{C}=\mathrm{f}^{*}\left(\exp ^{\wedge}(\mathrm{a}+\mathrm{bf})\right)$

3. $\mathrm{f}_{\mathrm{opt}}$ diperoleh dari turunan pertama $\mathrm{C} / \mathrm{f}=0$

$\mathrm{f}_{\mathrm{opt}}=-(1 / \mathrm{b})$

4. MSY diperoleh dengan mensubstitusikan $\mathrm{f}_{\mathrm{opt}}$ ke dalam persamaan 7 sehingga didapatkan:

MSY $=-(1 / b) * \mathrm{e}^{\wedge}(\mathrm{a}-1) \ldots \ldots \ldots \ldots \ldots \ldots \ldots . . . . \ldots$

\section{Tingkat Pemanfaatan (TP) dan Tingkat Kapasitas (TK)}

Menurut Sparre dan Venema (1999), tingkat pemanfaatan dinyatakan dalam persen (\%), dinyatakan dalam rumus:

$\mathrm{TP}_{(\mathrm{i})}=\left(\mathrm{C}_{\mathrm{i}} / \mathrm{MSY}\right) \times 100 \%$

keterangan:

$\mathrm{TP}_{(\mathrm{i})}$ : tingkat pemanfaatan tahun ke-i

$\mathrm{Ci}$ : hasil tangkapan tahun ke-i

MSY : hasil tangkapan maksimum lestari

Demikian juga tingkat kapasitas, dinyatakan dalam persen (\%) dan dirumuskan:

$\mathrm{TK}_{(\mathrm{i})}=\left(\mathrm{f}_{\mathrm{i}} / \mathrm{f}_{\mathrm{opt}}\right) \times 100 \%$

keterangan:

$\mathrm{TK}_{(\mathrm{i})}$ : tingkat kapasitas penangkapan tahun ke-i

$\mathrm{f}_{\mathrm{i}} \quad$ : jumlah effort tahun ke-i $\mathrm{f}_{\mathrm{opt}} \quad$ : jumlah effort optimum

\section{HASIL DAN PEMBAHASAN}

\section{Catch per Unit Effort (CPUE)}

Perhitungan nilai CPUE biasa digunakan untuk mengetahui perkembangan stok ikan, dan sebagai indikator efisiensi operasi penangkapan ikan yang potensial dan efektif tanpa perlu data sebanyak metode lain (van Hoof dan Salz, 2001). Nilai CPUE diperoleh dengan membagi data antara hasil tangkapan (catch) dan jumlah effort yang sudah distandarisasi. Perikanan skala kecil di Kota Semarang yang bersifat multyspecies dan multygear ini diambil 4 jenis ikan dominan, yaitu: teri, tembang dan kembung serta petek. Jenis alat tangkap dominan yang digunakan untuk menangkap keempat jenis ikan dominan tersebut adalah Gill Net, Arad dan Bagan. Alat yang dijadikan standart adalah yang memiliki c/a tertinggi atau FPI=1 yaitu Bagan. Nilai CPUE perikanan skala kecil di Kota Semarang tahun 2010-2019 disajikan dalam Tabel 1.

Tren perkembangan atau penurunan nilai CPUE dapat terlihat dari hubungan CPUE dengan effort-nya. Tren CPUE ini dapat menggambarkan indikasi status pemanfaatan sumberdaya ikan di suatu perairan. Mengenai hubungan CPUE dan effort pada perikanan skala kecil di Kota Semarang dapat terlihat pada Gambar 2.

Tabel 1. Nilai CPUE perikanan skala kecil di Kota Semarang tahun 2010-2019

\begin{tabular}{cccc}
\hline Tahun & Produksi (ton/thn) & Effort (unit) & CPUE \\
\hline 2010 & 156,00 & 466 & 0,33 \\
2011 & 164,00 & 784 & 0,21 \\
2012 & 175,00 & 466 & 0,38 \\
2013 & 372,00 & 466 & 0,80 \\
2014 & 568,00 & 481 & 1,18 \\
2015 & 583,00 & 481 & 1,21 \\
2016 & 594,00 & 865 & 0,69 \\
2017 & 606,00 & 1032 & 0,59 \\
2018 & 517,00 & 1199 & 0,43 \\
2019 & 352,00 & 1199 & 0,29 \\
\hline
\end{tabular}




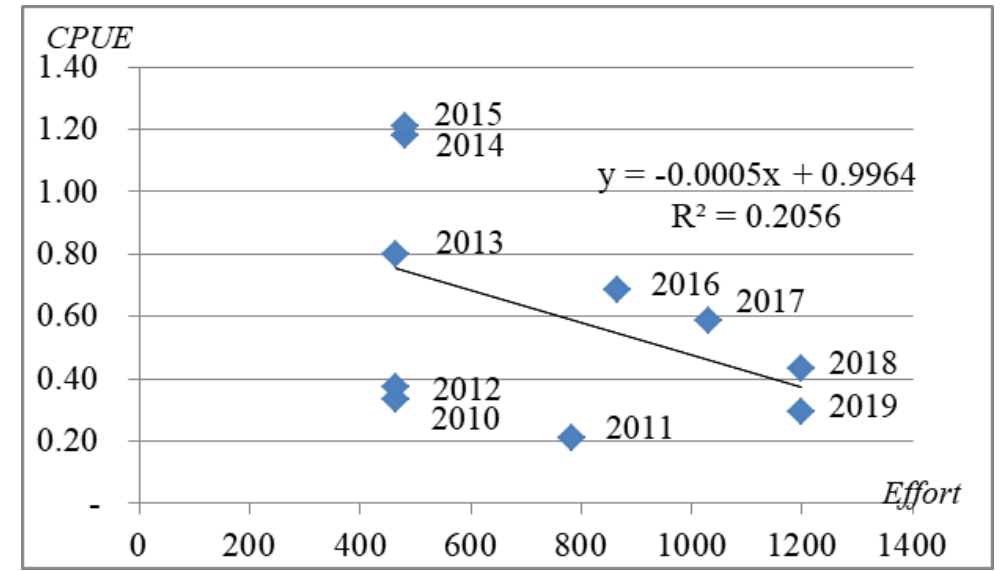

Gambar 2. Hubungan CPUE dan effort

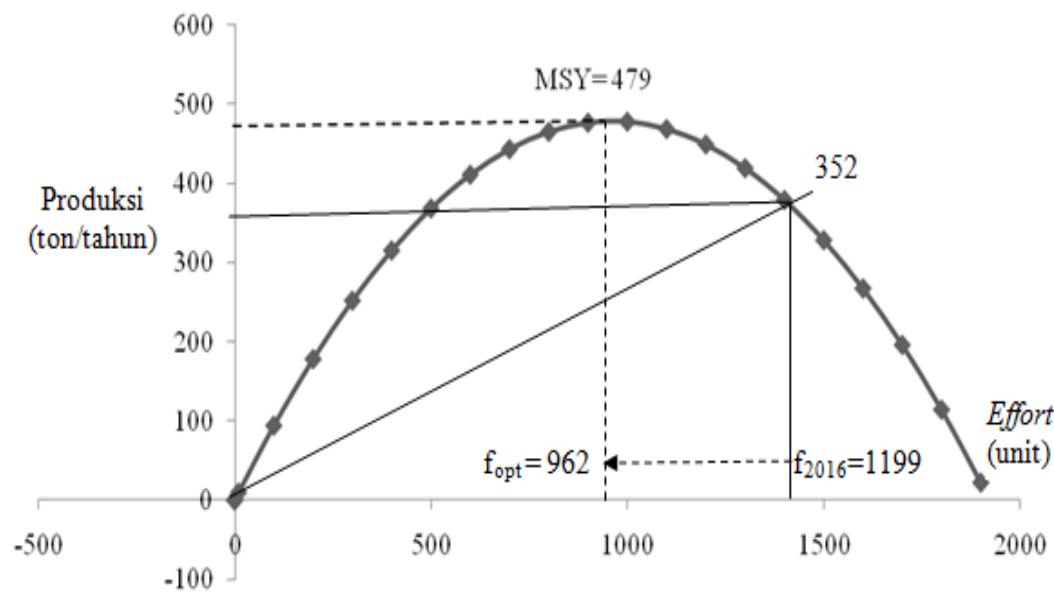

Gambar 3. MSY dan $\mathrm{f}_{\text {opt }}$ model Schaefer.

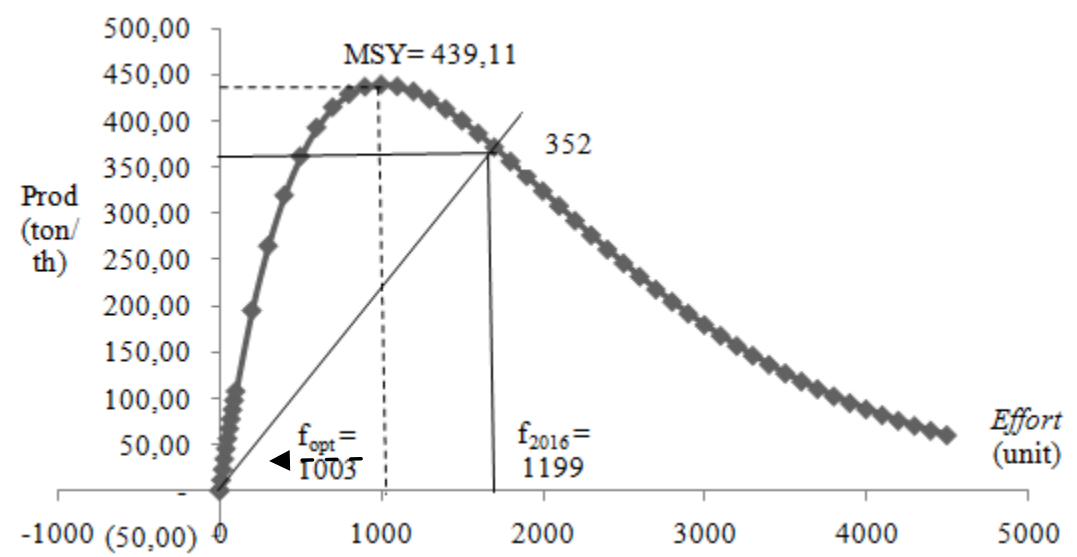

Gambar 4. MSY dan $\mathrm{f}_{\mathrm{opt}}$ model Fox.

Pada Gambar 2 terlihat bahwa hubungan CPUE dan effort memiliki tren CPUE yang menurun. Penurunan nilai CPUE ini mengindikasikan status pemanfaatan sumberdaya ikan di perairan Kota Semarang mengalami overfishing. Hal ini sesuai dengan (Jaya et al. 2017) yang menyatakan penurunan CPUE mengindikasikan tingkat pemanfaatan sumberdaya ikan mengalami overfishing. Penurunan nilai CPUE juga dapat menunjukkan operasi penangkapan semakin tidak efisien. Ketidakefisienan ini terjadi karena hasil tangkapan yang diperoleh semakin kecil dengan penggunaan jumlah effort yang semakin besar, sehingga perlu analisis lebih lanjut untuk dapat menentukan jumlah optimumnya.

\section{MSY dan $\mathbf{f}_{\text {opt }}$}

Hasil analisis potensi maksimum lestari (MSY) pada perikanan skala kecil di Kota Semarang menurut model Schaefer adalah 479 ton/tahun dan jumlah alat tangkap optimum yang dapat dioperasikan $\left(\mathrm{f}_{\mathrm{opt}}\right)$ adalah 962 unit. Menurut model Fox diperoleh hasil MSY sebesar 439,11 ton/tahun dan $\mathrm{f}_{\text {opt }}$ sebesar 1.003 unit, seperti yang tersaji dalam Gambar 3 dan 4. 
Pada Gambar 3 (Model Schaefer) terlihat bahwa jumlah unit penangkapan yang digunakan oleh nelayan ( $f_{\text {existing }}$ ) di Kota Semarang pada tahun 2019 (sebesar 1.199 unit) telah melebihi jumlah alat tangkap optimumnya (sebesar 1.003 unit), sehingga telah terjadi kelebihan kapasitas penangkapan (overcapacity). Kelebihan kapasitas ini menyebabkan hasil tangkapan atau produksi perikanan skala kecil Kota Semarang tahun 2019 sebesar 352 ton per-tahun telah melewati nilai potensi lestari (MSY) sebesar 479 ton per-tahun. Ini menunjukan bahwa perikanan skala kecil di Kota Semarang telah terjadi tangkap lebih (overfishing). Terkait dengan kebijakan, maka kelebihan kapasitas ini tentunya perlu dikurangi agar sumberdaya perikanan dapat dikelola secara berkelanjutan. Berdasarkan model Schaefer tersebut maka jumlah unit penangkapan yang beroperasi ( $f_{\text {existing }}$ ) sebesar 1.199 unit seharusnya dikurangi sebanyak 237 unit agar kembali berada pada kondisi optimumnya yaitu sebesar 962 unit. Pada model Schaefer ini memiliki kelemahan yaitu dengan penambahan effort yang terus menerus (tidak terkendali), maka lama kelamaan potensi sumberdaya perikanan akan habis $\left(\mathrm{Y}_{\mathrm{t}}=0\right)$. Hal ini terlihat pada bentuk grafik parabola terbalik pada Gambar 3 dengan produksi akhir sama dengan 0 (habis), padahal kenyataannya sumberdaya perikanan bersifat dapat pulih (renewable resoursces) dan dapat melakukan regenerasi, sehingga tidak mungkin sampai benarbenar habis. Untuk itu pada penelitian ini dipertimbangkan juga Model Fox untuk menutupi kelemahan yang terdapat pada model Schaefer.

Pada Gambar 4 (Model Fox), terlihat grafik berbentuk exponensial, dimana tekanan terhadap sumberdaya perikanan yang terus menerus oleh jumlah alat tangkap (effort) yang berlebihan, sumberdaya perikanan tidak sampai habis/punah $(\mathrm{Yt} \neq 0)$. Kondisi ini tentunya lebih realistis sesuai dengan kondisi di lapangan bahwa sumberdaya perikanan bersifat renewable resoursces. Hasil perhitungan nilai MSY pada model Fox ini diperoleh sebesar 439,11 ton per-tahun dengan jumlah alat tangkap (effort) optimumnya sebesar 1003 unit. Sedangkan pada kondisi eksistingnya yaitu hasil produksi perikanan skala kecil di Kota Semarang tahun 2019 sebesar 352 ton per-tahun dengan jumlah effort sebanyak 1199 unit juga telah melewati nilai MSY, sehingga termasuk dalam kategori tangkap lebih (overfishing), dengan kelebihan effort sebanyak 196 unit yang harus dikurangi.

Terjadinya kondisi overfishing pada perikanan skala kecil di Kota Semarang ini juga diperkuat oleh (Anas et al. 2011), yang menyebutkan bahwa status pemanfaatan sumberdaya ikan di Perairan Cirebon (yang merupakan Pantai Utara Jawa dan bagian WPP 712) mengalami overfishing. Hal ini ditandai dengan kecenderungan volume hasil tangkapan yang semakin sedikit, ukuran ikan hasil tangkapan yang semakin kecil dan waktu yang dipergunakan untuk melaut semakin besar/lama. Pendapat yang sama juga disampaikan (Triarso, 2012), yang menyatakan bahwa potensi sumberdaya perikanan di Pantura Jateng terindikasi mengalami overfishing, karena tekanan penangkapan yang dilakukan perikanan skala kecil yang biasa beroperasi di pantai.

\section{Tingkat Pemanfaatan (TP) dan Tingkat Kapasitas (TK)}

Tingkat pemanfaatan sumberdaya perikanan menunjukkan perbandingan jumlah produksi tangkapan tahunan dengan potensi maksimum lestarinya (MSY) dan dinyatakan dalam persen. Demikian pula untuk tingkat kapasitas penangkapan merupakan perbandingan jumlah effort existing tahunan dengan jumlah effort optimumnya yang dinyatakan dalam persen. Hasil perhitungan mengenai tingkat pemanfaatan sumberdaya perikanan dan tingkat kapasitas penangkapan pada perikanan skala kecil di Kota Semarang ditunjukkan pada Tabel 2.

Pada Tabel 2 terlihat bahwa tahun 2014 hingga 2016 TP > 100\% dan TK $<100 \%$ yang berarti tingkat pemanfaatan sumberdaya perikanan di Kota Semarang telah melebihi potensi lestarinya (telah terjadi over-exploited), namun peningkatan kapasitas penangkapan masih di bawah nilai optimumnya (belum terjadi overcapacity). Pada tahun 2017 dan 2018 baik TP maupun TK > 100\%, artinya tingkat kapasitas penangkapan telah melebihi nilai optimumnya (telah terjadi overcapacity) dan tingkat pemanfaatannya telah melebihi MSY ((telah terjadi over-exploited). Tahun 2019 penurunan tingkat pemanfaatan $(\mathrm{TP}<100 \%)$ terjadi karena stok sumberdaya ikan sudah menurun (pernah mengalami over-exploited pada tahun sebelumnya) akibat terjadi overcapacity (TK > 100\%). Secara keseluruhan dapat dikatakan bahwa sumberdaya perikanan skala kecil di Kota Semarang telah mengalami over-exploited yang ditandai nilai TP $>100 \%$, serta mengalami overcapacity yang terlihat dari perolehan nilai tingkat kapasitas penangkapan (TK) yang nilainya lebih dari $100 \%$. 
Tabel 2. Tingkat pemanfaatan dan tingkat kapasitas perikanan skala kecil di Kota Semarang tahun 2010-2019

Tahun Produksi (ton/thn) $\quad$ Effort (unit) $\quad$ TP*(\%) $\quad$ TP**(\%) $\quad$ TK* $(\%) \quad$ TK** (\%)

\begin{tabular}{ccccccc}
\hline 2010 & 156 & 466 & 33 & 36 & 48 & 46 \\
2011 & 164 & 784 & 34 & 37 & 81 & 78 \\
2012 & 175 & 466 & 37 & 40 & 48 & 46 \\
2013 & 372 & 466 & 78 & 85 & 48 & 46 \\
2014 & 568 & 481 & 119 & 129 & 50 & 48 \\
2015 & 583 & 481 & 122 & 133 & 50 & 48 \\
2016 & 594 & 865 & 124 & 135 & 90 & 86 \\
2017 & 606 & 1032 & 127 & 138 & 107 & 103 \\
2018 & 517 & 1199 & 108 & 118 & 125 & 120 \\
2019 & 352 & 1199 & 73 & 80 & 125 & 120 \\
\hline
\end{tabular}

* (model Schaefer) dengan MSY $=479$ ton/tahun dan $\mathrm{f}_{\text {opt }}=962$ unit

** (model Fox) dengan MSY $=439,11$ ton/tahun dan $\mathrm{f}_{\text {opt }}=1.003$ unit

\section{Kebijakan Pengelolaan}

Berdasarkan analisis tren CPUE yang sudah mengalami penurunan sejak tahun 2016 sampai 2019; analisis MSY yang menunjukkan hasil tangkapan atau produksi perikanan (existing) telah melewati potensi lestarinya sehingga stok sumberdaya ikan menurun; serta analisis tingkat pemanfaatan (TP) yang melebihi $100 \%$, maka perikanan skala kecil di Kota Semarang dimasukkan dalam kategori over-exploited. Hal ini telah sesuai dengan penetapan oleh FAO (1995), status pemanfaatan sumberdaya ikan mengalami over-exploited dengan ditandai stok sumberdaya ikan sudah menurun karena tereksploitasi melebihi MSY-nya.

Berdasarkan analisis jumlah effort optimum $\left(\mathrm{f}_{\mathrm{opt}}\right)$ yang menunjukkan jumlah effort yang dioperasikan ( $f_{\text {existing }}$ ) tahun 2019 telah melebihi nilai optimumnya $\left(f_{\text {existing }}>f_{\text {opt }}\right.$ ) serta hasil analisis tingkat kapasitas penangkapan (TK) yang diperoleh hasil nilai TK lebih dari $100 \%$ sejak tahun 2017-2019 sehingga perikanan skala kecil di Kota Semarang telah mengalami kelebihan kapasitas penangkapan (overcapacity). Terjadinya over-exploited dan overcapacity pada perikanan skala kecil di Kota Semarang menguatkan hasil penelitian Malik, et al. (2019a,b).

Kelebihan kapasitas penangkapan akibat effort yang berlebihan ini harusnya dikurangi atau diturunkan sebesar 237 unit (Schaefer) atau 196 unit (Fox) agar kelestarian sumberdaya ikan dapat dipulihkan dan tidak terganggu, sehingga pemanfaatan sumberdaya ikan dapat berkelanjutan. Namun kebijakan pengelolaan perikanan dengan pengurangan kapasitas berlebih pada perikanan skala kecil ini, implementasi di lapangan banyak faktor yang mempengaruhi dan menjadi pertimbangan, diantaranya implikasi sosial ekonomi (perkembangan jumlah nelayan, mata pencaharian/ kesempatan kerja, pendapatan dan ketergantungan nelayan pada sumberdaya lokal). Solusi yang dapat diambil dalam mengatasi kelebihan kapasitas pada perikanan skala kecil yaitu dengan:(1) membatasi/melarang penggunaan alat tangkap yang tidak ramah lingkungan; (2) menciptakan mata pencaharian alternatif; (3) membentuk kelembagaan (Pomeroy 2011).

\section{KESIMPULAN}

Status perikanan skala kecil di Kota Semarang berada pada tingkat over-exploited. Hal ini ditandai dengan pengamatan di lapangan yang menunjukkan volume hasil tangkapan yang cenderung semakin sedikit, dan ukuran ikan hasil tangkapan cenderung semakin kecil. Berdasarkan analisis tren CPUE yang menurun, analisis MSY yang menunjukan produksi hasil tangkapan eksisting telah melewati potensi lestarinya dan analisis tingkat pemanfaatan yang melebihi nilai MSY (> 100\%). Kelebihan kapasitas penangkapan (overcapacity) menjadi penyebab terjadinya overfishing tersebut, berdasarkan analisis effort optimum $\left(\mathrm{f}_{\mathrm{opt}}\right)$ yang menunjukkan jumlah alat tangkap yang beroperasi ( $f_{\text {existing }}$ ) telah melebihi nilai optimumnya; serta analisis tingkat kapasitas penangkapan (TK) yang telah mencapai lebih dari $100 \%$. Solusi kebijakan pengelolaan yang dapat dilakukan oleh Pemerintah Daerah agar dapat berkelanjutan, diantaranya pembatasan atau pengurangan alat tangkap akibat kelebihan kapasitas (overcapacity). 


\section{DAFTAR PUSTAKA}

Anas P. 2011. Studi keterkaitan antara sumberdaya ikan dan kemiskinan nelayan sebagaì dasar kebìjakan pengelolaan wìlayah pesisir Kabupaten Cirebon, Provinsi Jawa Barat [Disertasi]. FPIK. Bogor: IPB University.

Batista VS, Fabre NN, Malhado ACM, Ladle RJ. 2013. Tropical artisanal coastal fisheríes: challenges and future directions. Fish Science \& Aquaculture. 22(1): 1-15.

[FAO] Food and Agricultural Organization. 1995. Tata laksana untuk perikanan yang bertanggung jawab. Terjemahan dari: Code of conduct for responsíble fisheries. Jakarta (ID): FAO, Deptan, JICA.

[FAO] Food and Agriculture Organization of the United Nations. 2017. http://www.fao.org/fi/glossary. [Diakses pada tanggal 7 Pebruari 2017].

Garcia SM, Allison EH, Andrew NJ, Bene C, Bianchi G, de-Graaf GJ, Kalikoski D, Mahon R, Orensanz JM. 2008. Towards integrated assessment and advice in small scale físheríes: principles and processes. FAO Físheríes and Aquaculture Technical Paper, No. 515. Rome (IT): FAO. 84 p.

Guyader O, Berthou P, Koutsikopoulos C, Alban F, Demanecheb S, Gaspare MB, Eschbaum R, Fahy E, Tully O, Reynal L, Curtil O, Frangoudes K, Maynou F. 2012. Small scale fisheries in Europe: A comparative analysis based on a selectionof case studies. Fisheries Research. 140: 1-13.

Istikasari I, Mudzakir AK, Wijayanto D. 2016. Analisis bioekonomi rajungan (Portunus pelagícus) menggunakan pendekatan swept area dan Gordon Schaefer di Perairan Demak. Prosiding Seminar Nasional Tahun ke-5 Hasil Penelitian Perikanan dan Kelautan. 433-447.

Jaya MM, Wiryawan B, Simbolon D. 2017. Analisis tingkat pemanfaatan sumber daya ikan Tuna dengan metode spawning potential ratio di Perairan Sendang Biru. Jurnal Ilmu dan Teknologi Kelautan Tropis. 9(2): 597604.

[KKP] Kementerian Kelautan dan Perikanan. 2016. Keputusan Menteri Kelautan dan Perikanan Nomor 47/KEPMEN-KP/2016 tentang Estimasi potensi, jumlah tangkapan yang diperbolehkan, dan tingkat pemanfaatan sumber daya ikan di Wilayah Pengelolaan Perikanan Negara Republik Indonesia. Jakarta (ID): KKP.

King M. 2007. Fisheries biology, assessment and management. Second Edition. Oxford (UK): Blackwell. 382 p.

Malik J, Fahrudin A, Bengen DG, Taryono. 2019a. Overfishing and overcapacity small scale fisheries in Semarang City. Jurnal Ilmu dan Teknik Kelautan Tropis. 11(2): 427-435.

Malik J, Fahrudin A, Bengen DG, Taryono. 2019b. Strategic policy for small-scale fisheries management in Semarang City, Indonesia. AACL Bioflux. 12(4): 1163-1173.

Mc Clanahan TR, Castíla J. 2007. Fisheries management; progress toward sustainability. Oxford (UK): Blackwell Publishing. 332 p.

Nugraha E, Koswara B, Yuniarti. 2012. Potensi lestari dan tingkat pemanfaatan ikan kurisi (Nemípterus japonícus) di Perairan Teluk Banten. Jurnal Perikanan dan Kelautan. 3(1): 91-98.

Omori KL, Hoeniga JM, Luehring MA, BaierLockhart K. 2016. Effects of under estimating catch and effort on surplus production models. Fisheries Research. 183: 138-145.

Pomeroy R. 2011. Managing overcapacity in small scale fisheries in Southeast Asia. Marine Policy. 36: 520-527.

[RI] Republik Indonesia. 2016. Undang-Undang No. 7 Tahun 2016 tentang Perlindungan dan pemberdayaan nelayan, pembudi daya ikan dan petambak garam. Jakarta (ID): Setneg RI.

Sparre P, Venema SC. 1999. Introduksi Pengkajian Stok Ikan Tropis. Jakarta (ID): FAO dan Puslitbang Perikanan. 436 hal.

Tínungki GM. 2005. Evaluasi model produksi surplus dalam menduga hasil tangkapan maksimum lestari untuk menunjang kebijakan pengelolaan perikanan Lemuru di Selat Bali [Disertasi]. FPIK. Bogor (ID): IPB University.

Triarso I. 2012. Potensi dan peluang pengembangan usaha perikanan tangkap di Pantura Jawa Tengah. Jurnal Saintek Perikanan. 8(1): 65-73.

Trimble M, Johnson D. 2012. Artisanal fishing as an undesirable way of life? The implications for governance of fishers wellbeing aspirations in coastal Uruguay and south eastern Brazil. Mar. Policy. 37: 37-44.

van Hoof L, Salz P. 2001. Applying CPUE as management tool. Discussion paper EAFE Conference 2001. 10 p.

Zulbainarni N. 2016. Teori dan Praktik Pemodelan Bioekonomi dalam Pengelolaan Perikanan Tangkap. Edisi Revisi. Bogor (ID): IPB Press. 338 hal. 